\title{
Optimizing Loco Regional Management of Oligometastatic Colorectal Cancer: Technical Aspects and Biomarkers, Two Sides of the Same Coin
}

\author{
Giovanni Mauri ${ }^{1,2} \mathbb{D}^{D}$, Lorenzo Monfardini ${ }^{3, *}$, , Andrea Garnero ${ }^{4,5}$, Maria Giulia Zampino ${ }^{6}$, Franco Orsi ${ }^{1}$, \\ Paolo Della Vigna ${ }^{1}$ (D), Guido Bonomo ${ }^{1}$, Gianluca Maria Varano ${ }^{1}$ (D), Marco Busso ${ }^{4}$, Carlo Gazzera ${ }^{7}$, \\ Paolo Fonio ${ }^{5,7}$, Andrea Veltri ${ }^{4,8}$ (D) and Marco Calandri ${ }^{4,8}$
}

Citation: Mauri, G.; Monfardini, L.; Garnero, A.; Zampino, M.G.; Orsi, F.; Della Vigna, P.; Bonomo, G.; Varano, G.M.; Busso, M.; Gazzera, C.; et al. Optimizing Loco Regional Management of Oligometastatic Colorectal Cancer: Technical Aspects and Biomarkers, Two Sides of the Same Coin. Cancers 2021, 13, 2617. https://doi.org/10.3390/ cancers 13112617

Academic Editor: Wim P. Ceelen

Received: 22 February 2021

Accepted: 22 May 2021

Published: 26 May 2021

Publisher's Note: MDPI stays neutra with regard to jurisdictional claims in published maps and institutional affiliations.

Copyright: (c) 2021 by the authors. Licensee MDPI, Basel, Switzerland. This article is an open access article distributed under the terms and conditions of the Creative Commons Attribution (CC BY) license (https:/ / creativecommons.org/licenses/by/ $4.0 /)$.
1 Divisione di Radiologia Interventistica, Istituto Europeo di Oncologia, IRCCS, 20141 Milan, Italy giovanni.mauri@ieo.it (G.M.); franco.orsi@ieo.it (F.O.); paolo.dellavigna@ieo.it (P.D.V.); guido.bonomo@ieo.it (G.B.); gianluca.varano@ieo.it (G.M.V.)

2 Dipartimento di Oncologia ed Emato-Oncologia, Università degli Studi di Milano, 20122 Milan, Italy

3 Divisione di Radiologia, Fondazione Poliambulanza, 25124 Brescia, Italy

4 Radiodiagnostica 1 U. A.O.U., San Luigi Gonzaga di Orbassano, Regione Gonzole 10, 10043 Orbassano, Torino, Italy; andrea.garnero@unito.it (A.G.); bussomarco@gmail.com (M.B.); andrea.veltri@unito.it (A.V.); marco.calandri@unito.it (M.C.)

5 Department of Surgical Sciences, University of Turin, 10124 Torino, Italy; paolo.fonio@unito.it

6 Divisione di Oncologia Medica Gastrointestinale e Tumori Neuroendocrini, Istituto Europeo di Oncologia, IRCCS, 20141 Milan, Italy; maria.zampino@ieo.it

7 Radiodiagnostica 1 U, A.O.U. Città della Scienza e della Salute, 10126 Torino, Italy; cgazzera@cittadellasalute.to.it

8 Department of Oncology, University of Turin, 10124 Torino, Italy

* Correspondence: lorenzo.monfardini@poliambulanza.it or lore.monfa@gmail.com

Simple Summary: The treatments for patients with oligometastatic colorectal carcinoma are rapidly evolving. The present review focuses on the role of minimally invasive techniques since they can now be used as an alternative to surgical management in selected cases in association with systemic therapies according to ESMO and NCCN guidelines. In recent years, biomarkers (both at molecular and imaging level) have emerged as a relevant and potential criteria for treatment strategy decision and will be crucial in the future for patients selection. Tumor molecular profile impacts on local outcome of image guide ablation as well as metabolic imaging which predicts the outcome of both percutaneous and trans-arterial treatments. Oncologists should be aware of advantages and disadvantages of those treatments options as well as the potential role of molecular profile for a better patient selection.

Abstract: Colorectal cancer (CRC) is the third most common cancer worldwide and has a high rate of metastatic disease which is the main cause of CRC-related death. Oligometastatic disease is a clinical condition recently included in ESMO guidelines that can benefit from a more aggressive locoregional approach. This review focuses the attention on colorectal liver metastases (CRLM) and highlights recommendations and therapeutic locoregional strategies drawn from the current literature and consensus conferences. The different percutaneous therapies (radiofrequency ablation, microwave ablation, irreversible electroporation) as well as trans-arterial approaches (chemoembolization and radioembolization) are discussed. Ablation margins, the choice of the imaging guidance as well as characteristics of the different ablation techniques and other technical aspects are analyzed. A specific attention is then paid to the increasing role of biomarkers (in particular molecular profiling) and their role in the selection of the proper treatment for the right patient. In conclusion, in this review an up-to-date state of the art of the application of locoregional treatments on CRLM is provided, highlighting both technical aspects and the role of biomarkers, two sides of the same coin.

Keywords: colorectal cancer; oligometastatic disease; surgery; loco regional treatments; chemotherapy 


\section{Introduction}

Colorectal cancer (CRC) is one of the most common malignant diseases, representing the second most frequent cause of cancer-related death in USA and in Europe [1].

Approximately $50 \%$ of CRC patients will present metastatic disease during their lifetime, half of them at diagnosis; liver being the most commonly involved site [2,3].

Currently, the management of metastatic disease is a major challenge and a multidisciplinary approach is necessary to optimize results by taking into consideration clinical characteristics and molecular classifications, thereafter tailoring treatment.

In contrast to diffuse metastatic disease, the concept of oligometastatic disease (OMD) was introduced by Hellman and Weichselbaum in 1995 as a transitional state between localized and diffuse metastatic burden; in recent years, this concept has gained wide consensus in CRC management [4].

In the OMD setting, optimal local control is essential to improve outcome [5,6].

When feasible, surgery (R0 resection) seems to be the best option with the greatest likelihood of cure for patients with CRC with limited liver metastases, with 5-year survival up to $40-50 \%$ [7-14].

Unfortunately, the majority (70-80\%) of patients are unsuitable candidates for resection due to clinical and/or surgical technical factors such as tumor size, location, multifocality, or inadequate hepatic reserve.

In this scenario, the role of interventional radiology is becoming increasingly important: complete ablation of all visible sites may affect local cure and may allow possible discontinuation of systemic therapy, thus inducing disease-free interval and quality of life improvement $[15,16]$. The European Society of Medical Oncology (ESMO) classified both surgical resection and thermal ablation as local ablative treatments (LATs) included in the treatment algorithm for OMD [6], underlining the importance of a multidisciplinary discussion when dealing with OMD patients.

For these reasons, patients with OMD should be carefully selected in order to optimize the results of the most modern technologies available even by means of specific biomarker investigation.

An extensive study is going on to biologically characterize oligometastatic CRC to provide a framework for its integrated classification and treatment [17].

The aim of our review is to report and highlight the key points of the application and the limitations of LATs performed by interventional radiologists in the setting of oligometastatic CRC treatment with special regard to the potentiality of biomarkers as predictors of LAT outcomes.

\section{Interventional Treatment Options for OMD CRC}

Interventional radiologists can provide different therapeutic strategies in the treatment of patients with oligometastatic CRC. From the technical perspective, interventional treatments can be divided in percutaneous ablative treatments and trans-arterial treatments.

\subsection{Image Guided Ablation Techniques}

Image-guided ablation techniques have been used mainly in the treatment of primary liver cancer [18], but in the last decade they have been more and more used in the treatment of oligometastatic CRC. With the application of different thermal or non-thermal energies under image guidance, it is possible to achieve the destruction of the desired amount of tissue through a percutaneously inserted applicator. Radiofrequency ablation (RFA) is by far the most often used technique for thermal ablation of the liver, given that it has been available for a longer time. More recent techniques such as microwave ablation (MWA), cryoablation, laser or irreversible electroporation (IRE) have been reported to be beneficial in this setting, showing promising results.

LATs can be performed both under general anesthesia as well as under conscious sedation, which consist of a drug-induced analgesia and depression of consciousness, during 
which patients respond purposefully to verbal commands, with adequate spontaneous ventilation and maintained cardiovascular function [19].

Some evidence suggest that general anesthesia should be favored over conscious sedation in order to reduce periprocedural perception of pain and increase local tumor progression-free survival [20] and expert consensus statements [21] highly recommend the diffusion of general anesthesia for the standardization of LATs. However, conscious sedation is still the most diffused approach in many western and eastern countries [22].

Table 1 shows pros and cons of the described techniques.

Table 1. Mechanism of actions and pros and cons of all different ablations techniques.

\begin{tabular}{|c|c|c|c|}
\hline Ablation Technique & Action & Pros & Cons \\
\hline RFA & $\begin{array}{l}\text { High frequency } \\
\text { alternating current } \\
\text { determining ion } \\
\text { friction, heat } \\
\text { generation and } \\
\text { coagulative necrosis }\end{array}$ & $\begin{array}{l}\text { Low-price * } \\
\text { Effective ablation of } \\
\text { lesions }<3 \mathrm{~cm} \\
\text { Equivalent to wedge } \\
\text { resection in small } \\
\text { metastases }\end{array}$ & $\begin{array}{l}\text { Difficult ablation of } \\
\text { lesions }>5 \mathrm{~cm} \\
\text { Heat-sink effect } \\
\text { Injury to nearby } \\
\text { organs }\end{array}$ \\
\hline MWA & $\begin{array}{l}\text { Microwaves } \\
\text { determining heat } \\
\text { generation and } \\
\text { coagulative necrosis }\end{array}$ & $\begin{array}{l}\text { No heat-sink effect } * * \\
\text { Larger zones of } \\
\text { ablation } \\
\text { Preferable for lesions } \\
>3 \mathrm{~cm} \\
\text { Reduced ablation and } \\
\text { anesthesia time }\end{array}$ & $\begin{array}{l}\text { Expensive * } \\
\text { Injury to nearby } \\
\text { organs }\end{array}$ \\
\hline Cryoablation & $\begin{array}{l}\text { Ice crystal formation } \\
\text { leading cell death and } \\
\text { tumor ischemia }\end{array}$ & $\begin{array}{l}\text { Visualization of } \\
\text { ice-ball during } \\
\text { procedure }\end{array}$ & $\begin{array}{l}\text { Expensive * } \\
\text { Cryoshock secondary } \\
\text { to cytokine release }\end{array}$ \\
\hline IRE & $\begin{array}{l}\text { Electrical pulses } \\
\text { determining cell } \\
\text { membranepores and } \\
\text { apoptosis }\end{array}$ & $\begin{array}{l}\text { No heat-sink effect } \\
\text { Effective for lesions } \\
<5 \mathrm{~cm} \\
\text { Indication for central, } \\
\text { perihilar lesions } \\
\text { Limited injury to } \\
\text { nearby vessels and } \\
\text { organs }\end{array}$ & $\begin{array}{l}\text { Expensive * } \\
\text { Difficult ablation of } \\
\text { lesions }>5 \mathrm{~cm} \\
\text { Placement of at least } \\
\text { two applicators } \\
\text { needed } \\
\text { ECG-gating necessary } \\
\text { General anesthesia } \\
\text { necessary and } \\
\text { operating room } \\
\text { required }\end{array}$ \\
\hline Laser Ablation & $\begin{array}{l}\text { Conversion of } \\
\text { absorbed light into } \\
\text { heat }\end{array}$ & $\begin{array}{l}\text { Smaller needle ( } 21 \mathrm{G}) \\
\text { Precise ablation area } \\
\text { Preferable for } \\
\text { multiple small and } \\
\text { variably sized lesions }\end{array}$ & $\begin{array}{l}\text { Expensive * } \\
\text { Limited size per } \\
\text { single insertion of } \\
\text { ablation areas }\end{array}$ \\
\hline
\end{tabular}
microwave ablation.

\subsubsection{Radiofrequency Ablation}

Ionic friction and heat generation, associated with protein denaturation and subsequent coagulative necrosis, are the main mechanisms behind RFA [23-27]. A high frequency alternating current is delivered from the tip of an electrode into the surrounding target tissue $[28,29]$. The alternating current determines movements in the ions within the tissue resulting in frictional heating. As the temperature rises above $60^{\circ} \mathrm{C}$, cellular necrosis is seen [30]. The device usually consists of a 14-17 Gauge needle, up to 15 to $25 \mathrm{~cm}$ long; it may contain hook-shaped electrode arms or tines used to obtain larger and more spherically shaped ablation volumes. Even if the interventional radiologists prefer the percutaneous approach, there is no consensus as to which is the best approach of needle insertion into 
the tumor, whether percutaneous or laparoscopic. RFA can be performed under ultrasound (US), computed tomography (CT), or magnetic resonance imaging (MRI) guidance, as well as using fusion imaging [31] depending on lesion visibility and operator experience. To control pain and minimize patient movement the procedure is usually performed under conscious sedation or general anesthesia $[16,32]$. Once the needle is in the right position within the target lesion and tines have been extended or deployed into the tumor, the electrode is connected to a generator and the ablation process is performed. RFA can reproduce a defined and predictable ablation area depending on the length of the exposed tip and the presence or absence of the hook-shaped electrode arms. Tumors which measure $<3 \mathrm{~cm}$ in maximal diameter can be easily ablated by placing the needle electrode in the center of the tumor [33]. Tumors measuring $>3 \mathrm{~cm}$ may require more than one needle electrode insertion, creating an overlapping ablation zone. To effectively destroy lesions that measure $\geq 5 \mathrm{~cm}$ in maximal diameter with currently available RFA devices can be challenging. Furthermore, similarly to surgery [34], the achievement of at least $5 \mathrm{~mm}$ (ideally $10 \mathrm{~mm}$ ) margins in all planes [34] is highly desirable in order to minimize residual disease and risk of local recurrence. Additionally, for this reason, some authors suggest a combined approach using both arterial embolization and percutaneous thermal ablation for large tumors [35].

Limitations of RFA include heat loss via nearby blood vessels ("heat-sink effect") and injury to nearby organs caused by heat propagation [36]. RFA could be potentially dangerous when treating lesions situated in challenging locations such as the hilum; moreover, despite the coagulation effect of RFA, bleeding represents a risk in percutaneous RFA (similarly to all the other percutaneous procedures). Protective techniques such as hydrodissection and bowel insufflation [24] can avoid such problems. Centrally located, perihilar metastases represent a poor indication for RFA; indeed their ablation could lead to biliary complications as well as lower efficacy of treatment due to surrounding large blood vessels. Nevertheless, the rate of major complications is low [37]. The adequate visualization of the target tumor seems to clearly impact the results of ablation [38]. Experimental results suggest that temperature mapping is a potential useful tool for RFA monitoring, allowing to estimate the achieved ablation zone and recognize an eventual heat sink effect [39]. Post ablation imaging (CT or MRI) is always required to assess results and monitor the ablated tissue over time. Relevantly, local efficacy of RFA has been reported by Elias et al. [40] to be equivalent to wedge resection in small metastases. The association of RFA with systemic treatment has significantly improved overall survival (OS) when compared with systemic treatment alone [16].

\subsubsection{Cryoablation}

The main principle of cryoablation is to determine cellular damage by rapid freezing of the tissue. The cooling and subsequent thawing of the needle leads to the freezing of the surrounding tissue by convection and conduction. The early cooling effect determines the formation of intracellular ice crystals causing cell membrane damage and death. The formation of ice crystals in the capillaries feeding the tumor mass leads to ischemia [41,42]. Percutaneous cryoablation can be performed under CT, MRI or US guidance [43]. Currently, cryoablation is still considered a more expensive tool compared to RFA and other ablation techniques, thus making it less popular among interventional radiologists. Ice ball formation within the vessels or biliary ducts can lead to injury and subsequent bleeding. A rare but possible complication is cryoshock, secondary to cytokine release by necrotic tissue, resulting in a systemic syndrome characterized by fever, tachycardia, and tachypnea.

To date, data regarding the use of cryoablation for metastatic CRC are limited when compared to RFA, since it is a relatively new technique and fewer centers use cryoablation for treating liver lesions. $\mathrm{Ng} \mathrm{KM}$ et al. [44] reported the results of cryoablation in 293 patients with unresectable colorectal metastases. Survival rates of 1, 3, 5 and 10 years were $87 \%, 41.8 \%, 24.2 \%$ and $13.3 \%$, respectively. These results are less encouraging when 
compared to RFA results. Further studies are needed to consolidate cryoablation as a treatment option of OMD CRC.

\subsubsection{Microwave Ablation}

In MWA, coagulative necrosis is induced by microwaves applied directly to the target tissue through a percutaneously placed antenna producing rapid temperature elevation [45-47]. In comparison to other ablative techniques, microwaves (between $300 \mathrm{MHz}$ and $300 \mathrm{GHz}$ in the electromagnetic spectrum) propagate well through all tissues including water vapor and charred desiccated tissue induced by the ablative process. As a result, microwaves provide more efficient heating than other ablation techniques, making them preferable in tissues with high blood supply or nearby vascular heat sinks [48]. Thanks to technological improvements, including applicator cooling device and power control of the microwave, this technique is very promising for the future [27,46,49,50] and is gaining popularity among interventionalists [22]. Ablation often takes less than $10 \mathrm{~min}$, typically averaging 3-7 min, improving overall efficiency and reducing anesthesia time. The major complication rate of MWA was reported as $4.6 \%$ when compared to $4.1 \%$ for RFA [51]. The most common complications include hemorrhage, portal vein thrombosis, bile leak/biloma, liver abscess, pleural effusion and tumor seeding. Nowadays, MWA is probably considered the most promising technology in the interventional management OMD CRC. Indeed, many prospective registries are open (such as CIEMAR, NCT03775980) and ongoing trials (such as the COLLISION, NCT03088150, [52]) are enrolling patients in order to establish the non-inferiority of this technique compared to surgery.

\subsubsection{Electroporation}

Electroporation is based on the use of electrical pulses created by monopolar electrodes (up to six) linked to an electrical generator, delivering a maximum of $50 \mathrm{~A}$ and $100 \mathrm{~V}$. This creates pores in cell membranes and consequent apoptoptic cell death due to increased permeability. The magnitude of the electrical field decreases from the center outwards. Electroporation can be reversible or irreversible, the latter causing cell death [53,54]. Outlined advantages of IRE include: no "heat sink effect" and limited or no injury to the vessels and organs in close proximity to the tumor. IRE is optimal for managing tumors smaller than $5 \mathrm{~cm}$ [55], indeed an important limitation is the incapability to completely ablate lesions larger than $5 \mathrm{~cm}$ without repeated attempts or repositioning of the electrodes [56]. A recent phase II study supports the potentiality of this technology in the CLM setting [57]. Due to the limitations of RFA and MWA on hilar tumors [58], despite a non-neglectable complication rate of IRE itself in this hard-to-reach CLM 57], the most likely future potential application of this technique will be as a niche indication in this setting.

\subsubsection{Laser Ablation}

In the last decade, lasers have been successfully used in the treatment of cancer and other diseases. Laser-induced interstitial thermotherapy (LITT) represents an effective and minimally invasive surgical technique in the treatment of various cancers such as liver, colorectal, lung, head and neck, brain, prostate and pancreas [59-64]. Near-infrared light from Nd:YAG laser or diode laser is applied given its ability to be readily and easily absorbed by human tissues [65]. Temperature distribution and dimension of the laserinduced damage are determined by thermal and optical properties of the treated tissue and by the features of the specific device [66]. One of the main advantages of LITT is the possibility to use a very small needle $(21 \mathrm{G})$ to reach the target lesion, thus also providing a very precise ablation area $[67,68]$. This makes LITT particularly valuable for lesions located in challenging positions, therefore reducing the procedure-related risks $[69,70]$. However, the literature is mostly focused on HCC management rather than OMD [71,72]. In the oligometastatic CRC setting, laser ablation has been applied even in the treatment of lung metastases [73]; in this context, when comparing the three different ablation methods, there were no significant differences in the time of tumor progression or in survival rates [74]. In conclusion, LITT diffusion for oligometastatic CRC treatment may be halted by the 
limited size of the ablation areas per single insertion, despite its potentiality for treating lesions in challenging sites.

\subsection{Transarterial Procedures}

\subsubsection{Transarterial Chemoembolization}

In transarterial chemoembolization (TACE), cytotoxic agents are injected directly into the tumour. In general, TACE consists of the injection of different types of chemotherapic agents mixed with microspheres or embolic particles such as lipiodol oil, collagen particles, trisacryl gelatin microspheres or polyvinyl alcohol particles, which shut down the tumoral blood flow as well as stimulate the release of high doses of the drug [75-79]. It is proved that ischemia increases vascular permeability and thereby promotes penetration of chemotherapeutic agents into the tumor with the advantage of maximizing local cytotoxic/ischemic damage as well as minimizing systemic side effects [80,81]. Drug-eluting beads transarterial chemoembolization (DEB-TACE) is a relatively new option for the treatment of CRC metastases. Its principle is based on the intra-arterial administration of drug-loaded beads to release chemotherapeutic agent into the tumour arterial network, whilst the embolization effect limits drug washout. DEB-TACE is generally used in patients with liver only or liver-dominant metastatic disease as well as in first-line, second-line, and salvage settings, without current consensus regarding the optimal treatment option. There are limited available data on this technique from single-arm studies. Two published randomized clinical trials (RCTs) evaluated different patient cohorts: the first RCT using DEB-TACE in combination with systemic FOLFOX (5-fluorouracil + leucovorin + oxaliplatin) as first-line therapy [82], with the second comparing DEB-TACE with systemic FOLFIRI (5-fluorouracil + leucovorin + irinotecan) in the third-line setting [79]. Overall progression-free survival was not significantly different between these groups. Mauri et al. [83] demonstrated that TACE with small-size particles loaded with irinotecan (DEBIRI) in patients with CRLM is a safe procedure and the promising results reported in terms of liver-specific progression-free survival and OS deserve further confirmation in larger prospective trials. Similarly to the hepatocellular carcinoma setting, some Authors [84-86] support the evidence that it is possible to obtain similar results with less toxicity using only drug-eluting polyvinyl alcohol microspheres ("beads"), without chemotherapy: in this way only, the ischaemic effect is used to treat the metastasis. However, data are still limited in the CRC setting requiring more robust evidence in the future.

\subsubsection{Hepatic Arterial Infusion of Chemotherapy}

Hepatic arterial infusion (HAI) consists of delivering antineoplastic drugs directly into liver metastases achieving a high drug concentration in the metastatic tissue, since early-stage lesions are mainly supplied by hepatic arteries [87].

Port-catheters can be surgically or percutaneously implanted. In patients treated with surgical resection, the catheter is inserted during laparotomy. For radiological percutaneous placements, the femoral artery is the preferred approach, reaching the hepatic artery via the gastroduodenal artery. The catheter is deployed near the hepatic artery root and subsequently connected to a subcutaneous port [88]. Retrospective studies show higher efficiency and lower local complication rates in the radiological approach when compared with the surgical one [89,90]. Complications include catheter migration, arterial obstruction, catheter thrombosis and catheter rupture with an overall rate of 30\% [91].

The high extraction ratios and the local drug concentrations of chemotherapeutic drugs achieved with HAI are the main features determining procedure rationale. The currently used drugs are oxaliplatin [92-95] in combination with floxuridine (FUDR) or 5-fluorouracil (5-FU). Regarding arterial infusion toxicity, Ducreux et al. demonstrated that oxaliplatin HAI has the same toxicity profile as intravenous infusion [95]. The use of intra-arterial and systemic chemotherapy combination demonstrates an improved outcome, indeed a tumor response rate up to $80 \%$ has been reported in patients treated with HAI-FUDR together with IV drugs (irinotecan/5-FU/oxaliplatin or oxaliplatin/irinotecan) [96,97]. 
In addition, in patients with high risk of recurrence, HAI-FUDR combined with systemic 5-FU seems to double disease-free survival when compared with treatment with systemic chemotherapy alone [98], even though this result does not imply an improved OS $[99,100]$. HAI can be considered a valid treatment option in patients with liver-limited disease in whom surgery or ablation techniques are not indicated. HAI can be considered as a second-line treatment if there is a poor response to first-line treatment and as salvage therapy or adjuvant therapy in unresectable liver metastases [101].

\subsubsection{Radioembolization}

The principle of selective internal radiation therapy (SIRT), also known as transarterial radioembolization (TARE), is the selective delivery of radioactively labelled particles to the target liver lesions via the hepatic artery, since tumors receive most of their blood supply from the hepatic artery rather than from the portal vein $[102,103]$. Resin or glass microspheres loaded with the b-emitting isotope yttrium-90 (90Y) are injected into the hepatic artery reaching the tumor vessels that have an average radius of $2.5 \mathrm{~mm}$. The tumor receives a dose higher than $120 \mathrm{~Gy}[104,105]$. Healthy liver tissue involvement is limited, since it is highly sensitive to radiation (around $35 \mathrm{~Gy}$ ) [106]. In general, radioembolization is performed as a monotherapy after systemic therapy failure [107]. Generally, SIRT procedure is well tolerated by patients, with only mild abdominal pain, fever, nausea and hepatic indices alteration occurring during the first week after treatment. Severe side effects are linked to deposition of the $90 \mathrm{Y}$ microspheres outside of the liver and consequent irradiation of normal tissue leading to radiation gastritis or ulceration $(10 \%)$, radiation pancreatitis $(<1 \%)$, and radiation cholecystitis $(<1 \%)$, potentially avoided with a careful work-up [108]. Current research, however, has begun to focus on the use of SIRT in combination with chemotherapy as first-line treatment for CRC metastases [109-111]: more studies are required to further develop TARE and improve patients selection; in particular, research on personalised dosimetry [112] may overcome the limitations of recently published trials that do not seem to demonstrate a clear impact on OS [113].

\section{Biomarkers}

In general, despite biomarkers having gained an increasing role in the development of drugs and medical devices [114], there is still significant confusion about their definition and use in clinical practice [115].

In 2016, a joint task force of the U.S. Food and Drug Administration (FDA) and the National Institutes of Health (NIH) forged common definitions of biomarkers and made them available to the public via a continuously updated online document - the "Biomarkers, Endpoints and other Tools" (BEST) resource.

Biomarker can define a "characteristic that is measured as an indicator of normal biological processes, pathogenic processes, or biological responses to an exposure or intervention, including therapeutic interventions. Molecular, histologic, radiographic, or physiologic characteristics are types of biomarkers". [116].

\subsection{Molecular Biomarkers}

In the era of targeted therapies, molecular biomarkers have emerged as important prognostic and predictive factors in CRC management to tailor systemic therapy and more recently also surgical and loco-regional treatments.

Tumours harboring mutations in the RAS family (KRAS, NRAS, HRAS) result in constitutive activation of the MAPK signalling pathway, and are unlikely to benefit from treatment with epidermal growth factor receptor (EGFR) antibodies [117].

$R A S$ testing should be carried out on all patients at the time of diagnosis of CRC and is mandatory before treatment with the EGFR-targeted monoclonal antibodies (i.e., panitumumab and cetuximab) [6]. Either primary CRC or liver metastatic tissue can be used for $R A S$ mutation testing, which have over $90 \%$ concordance in $R A S$ mutational status [6,118]. 
Only if primary tumor or liver metastases samples are not available may other metastatic sites (lymph node or lung metastases) be used [6].

Rat sarcoma (RAS) viral oncogene mutations are found in up to $40 \%$ of patients with $\mathrm{CRC}$ and have been associated with reduced survival after resection of primary CRC and CRLMs [119].

Positive RAS mutation status is associated with increased positive or narrower resection margins after CRLM surgical treatment [120]. Furthermore, $R A S$ mutation has been linked with higher incidence of disease recurrence and shorter OS in patients undergoing liver resection for CRLM [121].

Moreover, RAS mutation is associated with unsalvageable recurrence and with reduced survival after recurrence at any location after resection for CRLM [122].

Local tumor progression-free survival following percutaneous ablation of CRLMs was worse in patients with mutant $R A S$ than in patients with wild-type $R A S$ [123].

These findings support the hypothesis of a more infiltrative behavior of mutant $R A S$ CRLM, therefore knowledge of RAS mutations can guide surgical and interventional radiology procedures.

Briefly, while minimal ablation margins $>10 \mathrm{~mm}$ should be always the procedural goal, this becomes crucial for mutant RAS CRLM [124]. Mutant RAS patients should be considered candidates for ablation only if adequate ablation margins can be planned and obtained [125].

Other important molecular biomarkers used to guide patient selection, treatment decision, risk stratification and prognostication are $B R A F$ mutations, microsatellite instability (MSI) and co-occurring mutations in RAS/TP53 and APC/PIK3CA [126].

$B R A F$ is a protein kinase in the MAPK signalling pathway. In metastatic CRC, the most common $B R A F$ mutation results in a change at residue 600 that substitutes glutamine for valine (V600E). Of patients with metastatic CRC, 5-8\% carry BRAF V600E mutations [127]. Among these patients metastases are rarely limited to the liver, and those who undergo hepatectomy often develop disease recurrence at multiple sites, including peritoneum and lung [128,129]. Conversely, non-V600 BRAF mutations (harbored in $2 \%$ of metastatic CRC) correlate with significantly improved median OS compared with patients with wild-type $B R A F$ and are excellent candidates for CRLM resection [130]. RAS and BRAF mutational status should be assessed simultaneously for prognostic purposes [6].

Microsatellite instability (MSI) and subsequent deficient DNA mismatch repair (dMMR) are found both in sporadic and familial CRCs. dMMR in sporadic CRC is caused by an epigenetic inactivation of $M L H 1$ gene, correlating with the presence of BRAF V600E mutations [131]. Lynch syndrome is an autosomal dominant genetic disorder associated with germline mutation in dMMR genes. Although dMMR appears to be a favourable prognostic marker, $B R A F$ V600E mutations were observed in $45 \%$ of patients with deficient dMMR tumors conferring a worse prognosis [132].

The TP53 gene encodes a transcription factor which starts cell cycle arrest, DNA repair, apoptosis and angiogenesis in response to multiple cellular [133]. Loss of function of TP53 is present in $50-70 \%$ of patients with primary CRC [134].

Concomitant KRAS and TP53 mutations promote resistance to preoperative chemoradiation in locally advanced rectal cancer [135] and are associated with decreased OS after CRLM surgical treatment [136].

Adenomatous polyposis coli (APC) gene mutation lead to activation of the Wnt signalling pathway and is one of the earliest genetic events in CRC tumorigenesis; somatic $A P C$ mutations are observed in approximately $70 \%$ of sporadic CRCs. PIK3CA is a protooncogene encoding for a catalytic subunit of PI3K, involved in the PI3K/Akt/mTOR signalling pathway. PIK3CA mutations occur in $10-20 \%$ of CRC. Double mutation of APC and PIK3CA predicts poor response to preoperative chemotherapy and reduced OS in patients with CRLM resection [137]. Furthermore, preliminary data suggest that PI3K pathway mutation alone may predict longer time to local progression after CLM of SIRT [138]. 
Although mutational status is an important factor to consider in treatment planning, a different approach for improving patient survival is in developing biomarkers for early detection of primary and recurrent disease, at a point when traditional clinical indicators, such as radiographic signs, still are negative.

Liquid biopsy, including circulating tumor cells (CTCs), cell-free DNA (cfDNA), microRNA (miRNA), and exosomes, provides clinically or biologically relevant information about malignancies. Although still in development, potential applications of liquid biopsy include diagnosis, treatment response over time and minimal residual disease, in order to facilitate tailored therapy $[139,140]$.

Despite levels of CTCs correlating with prognosis in patients with CRC [141], the clinical utility of CTC measurement is yet to be defined [6]. Conversely, cfDNA assessment is emerging as a new tool for molecular profiling with greater possible clinical implications than CTCs $[6,142,143]$. cfDNA seems to be more sensitive in identifying the presence of multiple clinically relevant resistance mechanisms in comparison to single-lesion tumor biopsy, due to the multiple resistance alterations in an individual patient [144].

A summary of the more important molecular biomarkers and their implication in interventional treatments is provided in Table 2.

Table 2. Principal molecular biomarkers with their implications in interventional treatments.

\begin{tabular}{|c|c|c|c|c|}
\hline Biomarkers & $\begin{array}{c}\% \text { in Metastatic } \\
\text { CRC }\end{array}$ & Action & $\begin{array}{l}\text { Clinical and } \\
\text { Prognostic } \\
\text { Implications }\end{array}$ & $\begin{array}{l}\text { Interventional } \\
\text { Therapeutic } \\
\text { Implications }\end{array}$ \\
\hline$K-R A S$ & $15-50 \%$ & $\begin{array}{l}\text { Constitutive } \\
\text { activation of the } \\
\text { MAPK signalling } \\
\text { pathway }\end{array}$ & $\begin{array}{l}\text { Higher recurrence } \\
\text { rate after liver or } \\
\text { lung CRC } \\
\text { metastases } \\
\text { ablation } \\
\text { Reduced OS }\end{array}$ & $\begin{array}{l}\text { - Larger ablation } \\
\text { margins are strictly } \\
\text { required for } R A S \\
\text { mutant metastases }\end{array}$ \\
\hline \multirow[t]{2}{*}{$B R A F$} & \multirow[t]{2}{*}{$1-8 \%$} & \multirow[t]{2}{*}{$\begin{array}{l}\text { Constitutive } \\
\text { activation of the } \\
\text { MAPK signalling } \\
\text { pathway }\end{array}$} & $\begin{array}{l}V 600 E \text { mutation } \\
\text { Recurrence after } \\
\text { resection in } \\
\text { multiple site } \\
\text { (peritoneum and } \\
\text { lung) }\end{array}$ & \\
\hline & & & $\begin{array}{l}\text { Non-V600 mutation } \\
\text { Significantly } \\
\text { improved OS } \\
\text { compared with } \\
\text { wild-type BRAF }\end{array}$ & $\begin{array}{l}\text { - Excellent } \\
\text { candidates for } \\
\text { CRLM local } \\
\text { therapies }\end{array}$ \\
\hline MSI & $2-3 \%$ & $\begin{array}{l}\text { Deficient DNA } \\
\text { mismatch repair }\end{array}$ & & \\
\hline TP53 & $50-70 \%$ & $\begin{array}{l}\text { Cell proliferation } \\
\text { and cell death } \\
\text { dysregulation }\end{array}$ & $\begin{array}{l}\text { Concomitant TP53 } \\
\text { and KRAS } \\
\text { mutation } \\
\text { associated with } \\
\text { decreased OS after } \\
\text { CRLM resection }\end{array}$ & \\
\hline$A P C$ & $42-70 \%$ & $\begin{array}{l}\text { Constitutive } \\
\text { activation of Wnt } \\
\text { signalling pathway }\end{array}$ & $\begin{array}{l}\text { Concomitant } A P C \\
\text { and } P I K 3 C A\end{array}$ & $\begin{array}{l}\text { - } \mathrm{PI} 3 \mathrm{~K} \text { pathway } \\
\text { mutation predicts }\end{array}$ \\
\hline PIK3CA & $6-28 \%$ & $\begin{array}{l}\text { Constitutive } \\
\text { activation of } \\
\text { PI3K/Akt/mTOR } \\
\text { signalling pathway }\end{array}$ & $\begin{array}{l}\text { associated with } \\
\text { poor prognosis } \\
\text { after CRLM } \\
\text { resection }\end{array}$ & $\begin{array}{l}\text { progression after } \\
\text { radioembolization } \\
\text { of CRLM }\end{array}$ \\
\hline
\end{tabular}

\subsection{Imaging Biomarkers}

The need for defining and assessing surrogate imaging biomarkers in the setting of CRLM treated by image-guided therapies is a priority of the NIH and the Society of Interventional Radiology (SIR) [145]. 
Disease persistence and recurrence are major downsides of locoregional therapies such as ablation [146]. Consequently it is crucial to speed up the identification of patients at increased risk for ablation treatment failure by developing specific prognostic markers.

These markers can influence clinical decision-making both regarding further ablations within the same treatment session and early administration of adjuvant therapies. Snoeren et al. [147] carried pathologic evaluation of the needles after local ablation and demonstrated that adherence of proliferating tumor cells to the radiofrequency electrodes was an independent risk factor for shorter LTP-free survival. Biopsy samples from the core and the margins of the ablation zone and rapid tissue analysis using fluorescent stains could be proposed as intra-procedural indicators of complete tumor ablation [148]. Cornelis et al. [149] evaluated the potential advantage of pairing biopsy with immediately post-ablation PET/CT as on-site predictors of local tumor progression after ablation. PET/CT scan independently detects partial ablation without evidence of residual viable tumor by biopsy [149].

Likewise, it is necessary to assess imaging biomarkers of response and subsequent predictors of liver progression-free survival after radioembolization of CRLM. The Response Evaluation Criteria in Solid Tumors (RECIST) guideline, originally developed to assess response to cytotoxic chemotherapeutic agents, may not be sufficient to characterize early CRLM response treated with radioembolization in the salvage setting [150,151].

EORTC PET criteria, Choi criteria, and tumor attenuation criteria appear to be equally reliable surrogate imaging biomarkers of liver progression-free survival after radioembolization in patients with CRLM [150]. Shady et al. [152] demonstrated that PET/CTderived metabolic volume metrics (i.e., metabolic tumor volume, MTV, and total lesion glycolysis, TLG) are significant predictors of OS post-SIRT of CRLM and seem to be more valuable than SUVmax and SUVpeak in this setting. Further investigations are required in this setting, since in other studies, diffusion-weighted MRI performed better than PET/CT in the prediction of response to therapy and OS [151] after SIRT of hepatic metastases. Furthermore, DWI can be used as a biomarker for monitoring response of CRLMs even to $\mathrm{TACE}$, showing an increase in ADC values between pre- and post-treatment measurements in responding lesions [153].

\section{Conclusions and Future Perspectives}

$\mathrm{CRC}$ is one of the most common cancers worldwide and the treatment of OMD is challenging. Interventional radiology treatments are becoming increasingly popular both in curative and palliative management of these patients. Nevertheless, further studies are required to make these techniques fully standardized. Correct stratification and selection of patients for the right treatment at the right time during the course of the disease will be the real challenge for clinicians and researchers in the next years. Identifying and validating adequate molecular and imaging biomarkers will be the cornerstone for implementing interventional procedures in oligometastatic CRC.

Author Contributions: Conceptualization, G.M., M.C. and L.M.; methodology, M.C. and G.M.; validation, F.O., P.F., A.V., G.B. and P.D.V.; formal analysis, G.M.V., L.M. and A.G.; investigation, M.G.Z., C.G. and M.B.; writing-original draft preparation, M.C., G.M., L.M. and A.G.; writingreview and editing, F.O., G.M.V., M.B. and C.G.; supervision, F.O., A.V. and P.F. All authors have read and agreed to the published version of the manuscript.

Funding: This research received no external funding. The authors have no affiliations or financial involvement with any organization or entity with a financial interest in or financial conflict with the subject matter or materials discussed in the manuscript. No writing assistance was utilized in the production of this manuscript.

Conflicts of Interest: G.M. received speaking fee from GE (General Electric). All other authors declare no conflict of interest. 


\section{References}

1. Miller, K.D.; Siegel, R.L.; Khan, R.; Jemal, A. Cancer Statistics. Cancer Rehabil. 2018, 70, 7-30. [CrossRef]

2. Cunningham, D.; Atkin, W.; Lenz, H.-J.; Lynch, H.T.; Minsky, B.; Nordlinger, B.; Starling, N. Colorectal cancer. Lancet Lond. Engl. 2010, 375, 1030-1047. [CrossRef]

3. Fidler, M.M.; Soerjomataram, I.; Bray, F. A global view on cancer incidence and national levels of the human development index. Int. J. Cancer 2016, 139, 2436-2446. [CrossRef]

4. Hellman, S.; Weichselbaum, R.R. Oligometastases. J. Clin. Oncol. 1995, 13, 8-10. [CrossRef] [PubMed]

5. Wild, A.T.; Yamada, Y. Treatment Options in Oligometastatic Disease: Stereotactic Body Radiation Therapy-Focus on Colorectal Cancer. Visc. Med. 2017, 33, 54-61. [CrossRef]

6. Van Custem, E.; Cervantes, A.; Adam, R.; Sobrero, A.; Van Krieken, J.H.; Aderka, D.; Aranda Aguliar, E.; Bardelli, A.; Benson, A.; Bodoky, G.; et al. ESMO consensus guidelines for the management of patients with metastatic colorectal cancer. Ann. Oncol. 2016, 27, 1386-1422. [CrossRef]

7. Charnsangavej, C.; Clary, B.; Fong, Y.; Grothey, A.; Pawlik, T.M.; Choti, M.A. Selection of Patients for Resection of Hepatic Colorectal Metastases: Expert Consensus Statement. Ann. Surg. Oncol. 2006, 13, 1261-1268. [CrossRef] [PubMed]

8. Choti, M.A.; Sitzmann, J.V.; Tiburi, M.F.; Sumetchotimetha, W.; Rangsin, R.; Schulick, R.D.; Lillemoe, K.D.; Yeo, C.J.; Cameron, J.L. Trends in Long-Term Survival Following Liver Resection for Hepatic Colorectal Metastases. Ann. Surg. 2002, 235, 759-766. [CrossRef] [PubMed]

9. Jarnagin, W.R.; Fong, Y.; Ky, A.; Schwarts, L.H.; Paty, P.B.; Cohen, A.M.; Blumgart, L.H. Liver resection for metastatic colorectal cancer: Assessing the risk of occult irresectable disease. J. Am. Coll. Surg. 1999, 188, 33-42. [CrossRef]

10. Fernandez, F.G.; Drebin, J.A.; Linehan, D.C.; Dehdashti, F.; Siegel, B.A.; Strasberg, S.M. Five-Year Survival After Resection of Hepatic Metastases From Colorectal Cancer in Patients Screened by Positron Emission Tomography With F-18 Fluorodeoxyglucose (FDG-PET). Ann. Surg. 2004, 240, 438-450. [CrossRef]

11. Lise, M.; Bacchetti, S.; Da Pian, P.; Nitti, N.; Pilati, P. Patterns of Recurrence after Resection of Colorectal Liver Metastases: Prediction by Models of Outcome Analysis. World J. Surg. 2001, 25, 638-644. [CrossRef] [PubMed]

12. Morris, E.J.A.; Forman, D.; Thomas, J.D.; Quirke, P.; Taylor, E.F.; Fairley, L.; Cottier, B.; Poston, G. Surgical management and outcomes of colorectal cancer liver metastases. BJS 2010, 97, 1110-1118. [CrossRef]

13. Ferrarotto, R.; Pathak, P.; Maru, D.; Agarwal, A.; Overman, M.; Hoff, P.M.; Kopetz, S. Durable complete responses in metastatic col-orectal cancer treated with chemotherapy alone. Clin. Colorectal Cancer 2011, 10, 178-182. [CrossRef] [PubMed]

14. Zampino, M.; Magni, E.; Ravenda, P.; Cella, C.; Bonomo, G.; Della Vigna, P.; Galdy, S.; Spada, F.; Varano, G.; Mauri, G.; et al. Treatments for colorectal liver metastases: A new focus on a familiar concept. Crit. Rev. Oncol. 2016, 108, 154-163. [CrossRef] [PubMed]

15. Palussière, J.; Catena, V.; Buy, X. Percutaneous thermal ablation of lung tumors - Radiofrequency, microwave and cryotherapy: Where are we going? Diagn. Interv. Imaging 2017, 98, 619-625. [CrossRef]

16. Ruers, T.; Van Coevorden, F.; Punt, C.J.A.; Pierie, J.-P.E.N.; Borel-Rinkes, I.; Ledermann, J.A.; Poston, G.; Bechstein, W.; Lentz, M.-A.; Mauer, M.; et al. Local Treatment of Unresectable Colorectal Liver Metastases: Results of a Randomized Phase II Trial. J. Natl. Cancer Inst. 2017, 109. [CrossRef]

17. Pitroda, S.P.; Khodarev, N.N.; Huang, L.; Uppal, A.; Wightman, S.C.; Ganai, S.; Joseph, N.; Pitt, J.; Brown, M.; Forde, M.; et al. Integrated molecular subtyping defines a curable oligometastatic state in colorectal liver metastasis. Nat. Commun. $2018,9,1793$. [CrossRef] [PubMed]

18. Lencioni, R. Loco-regional treatment of hepatocellular carcinoma. Hepatology 2010, 52, 762-773. [CrossRef]

19. Klein, A.A.; Meek, T.; Allcock, E.; Cook, T.M.; Mincher, N.; Morris, C.; Nimmo, A.F.; Pandit, J.J.; Pawa, A.; Rodney, G.; et al. Recommendations for standards of monitoring during anaesthesia and recovery 2021: Guideline from the Association of Anaesthetists. Anaesthesia 2021. [CrossRef] [PubMed]

20. Puijk, R.S.; Plantes, V.Z.D.; Nieuwenhuizen, S.; Ruarus, A.H.; Vroomen, L.G.P.H.; De Jong, M.C.; Geboers, B.; Hoedemaker-Boon, C.J.; Thöne-Passchier, D.H.; Gerçek, C.C.; et al. Propofol Compared to Midazolam Sedation and to General Anesthesia for Percutaneous Microwave Ablation in Patients with Hepatic Malignancies: A Single-Center Comparative Analysis of Three Historical Cohorts. Cardiovasc. Interv. Radiol. 2019, 42, 1597-1608. [CrossRef]

21. Gillams, A.; Goldberg, N.; Ahmed, M.; Bale, R.; Breen, D.; Callstrom, M.; Chen, M.H.; Choi, B.I.; De Baere, T.; Dupuy, D.; et al. Thermal ablation of colorectal liver metastases: A position paper by an international panel of ablation experts, the interventional oncology sans frontières meeting 2013. Eur. Radiol. 2015, 25, 3438-3454. [CrossRef]

22. Calandri, M.; Gazzera, C.; Giurazza, F.; Yevich, S.; Strazzarino, G.A.; Brino, J.; Marra, P.; Contegiacomo, A.; Bargellini, I.; Cariati, M.; et al. Oligometastatic Colorectal Cancer Management: A Survey of the Italian College of Interventional Radiology. Cardiovasc. Interv. Radiol. 2020, 43, 1474-1483. [CrossRef] [PubMed]

23. Vogl, T.J.; Farshid, P.; Naguib, N.N.N.; Darvishi, A.; Bazrafshan, B.; Mbalisike, E.; Burkhard, T.; Zangos, S. Thermal ablation of liver metastases from colorectal cancer: Radiofrequency, microwave and laser ablation therapies. La Radiol. medica 2014, 119, 451-461. [CrossRef] [PubMed]

24. Garnon, J.; Cazzato, R.L.; Caudrelier, J.; Nouri-Neuville, M.; Rao, P.; Boatta, E.; Ramamurthy, N.; Koch, G.; Gangi, A. Adjunctive Thermoprotection During Percutaneous Thermal Ablation Procedures: Review of Current Techniques. Cardiovasc. Interv. Radiol. 2019, 42, 344-357. [CrossRef] 
25. Ridge, C.A.; Solomon, S.B. Percutaneous ablation of colorectal lung metastases. J. Gastrointest. Oncol. 2015, 6, 685-692.

26. Vroomen, L.; Petre, E.; Cornelis, F.; Solomon, S.; Srimathveeravalli, G. Irreversible electroporation and thermal ablation of tumors in the liver, lung, kidney and bone: What are the differences? Diagn. Interv. Imaging 2017, 98, 609-617. [CrossRef] [PubMed]

27. Livraghi, T.; Goldberg, S.N.; Lazzaroni, S.; Meloni, F.; Ierace, T.; Solbiati, L.; Gazelle, G.S. Hepatocellular Carcinoma: Radiofrequency Ablation of Medium and Large Lesions. Radiology 2000, 214, 761-768. [CrossRef]

28. Healey, T.T.; Dupuy, D.E. Radiofrequency ablation: A safe and effective treatment in nonoperative patients with early-stage lung cancer. Cancer J. 2011, 17, 33-37. [CrossRef]

29. Choi, T.W.; Lee, J.M.; Lee, D.H.; Yu, S.J.; Kim, Y.J.; Yoon, J.-H.; Han, J.K.; Lee, J.-H. Percutaneous Dual-Switching Monopolar Radiofrequency Ablation Using a Separable Clustered Electrode: A Preliminary Study. Korean J. Radiol. 2017, 18, 799-808. [CrossRef]

30. Rossi, S.; Garbagnati, F.; Lencioni, R.; Allgaier, H.-P.; Marchianò, A.; Fornari, F.; Quaretti, P.; Di Tolla, G.; Ambrosi, C.; Mazzaferro, V.M.; et al. Percutaneous Radio-frequency Thermal Ablation of Nonresectable Hepatocellular Carcinoma after Occlusion of Tumor Blood Supply. Radiology 2000, 217, 119-126. [CrossRef] [PubMed]

31. Mauri, G. Expanding role of virtual navigation and fusion imaging in percutaneous biopsies and ablation. Abdom. Imaging 2015, 40, 3238-3239. [CrossRef] [PubMed]

32. Venkatesan, A.M.; Gervais, D.A.; Mueller, P.R. Percutaneous Radiofrequency Thermal Ablation of Primary and Metastatic Hepatic Tumors: Current Concepts and Review of the Literature. Semin. Interv. Radiol. 2006, 23, 073-084. [CrossRef] [PubMed]

33. Veltri, A.; Sacchetto, P.; Tosetti, I.; Pagano, E.; Fava, C.; Gandini, G. Radiofrequency Ablation of Colorectal Liver Metastases: Small Size Favorably Predicts Technique Effectiveness and Survival. Cardiovasc. Interv. Radiol. 2008, 31, 948-956. [CrossRef]

34. Rhim, H.; Goldberg, S.N.; Dodd, G.D.; Solbiati, L.; Lim, H.K.; Tonolini, M.; Cho, O.K. Essential Techniques for Successful Radio-frequency Thermal Ablation of Malignant Hepatic Tumors. Radiology 2001, 21, S17-S35. [CrossRef] [PubMed]

35. Iezzi, R.; Pompili, M.; Posa, A.; Coppola, G.; Gasbarrinim, A.; Bonomo, L. Combined locoregional treatment of patients with hepa-tocellular carcinoma: State of the art. World J. Gastroenterol. 2016, 22, 1935-1942. [CrossRef]

36. McGhana, J.; Dodd, G. Radiofrequency ablation of the liver: Current status. Am. J. Roentgenol. 2001, 176, 3-16. [CrossRef]

37. Koda, M.; Murawaki, Y.; Hirooka, Y.; Kitamoto, M.; Ono, M.; Sakaeda, H.; Joko, K.; Sato, S.; Tamaki, K.; Yamasaki, T.; et al. Complications of radiofrequency ablation for hepatocellular carcinoma in a multicenter study: An analysis of 16346 treated nodules in 13283 patients. Hepatol. Res. 2012, 42, 1058-1064. [CrossRef] [PubMed]

38. de Baere, T.; Tselikas, L.; Yevich, S.; Boige, V.; Deschamps, F.; Ducreux, M.; Goere, D.; Nguyen, F.; Malka, D. The role of image-guided therapy in the management of colorectal cancer metastatic disease. Eur. J. Cancer 2017, 75, 231-242. [CrossRef]

39. Rempp, H.; Hoffmann, R.; Roland, J.; Buck, A.; Kickhefel, A.; Claussen, C.D.; Pereira, P.L.; Schick, F.; Clasen, S. Threshold-based prediction of the coagulation zone in sequential temperature mapping in MR-guided radiofrequency ablation of liver tumours. Eur. Radiol. 2011, 22, 1091-1100. [CrossRef]

40. Elias, D.; Baton, O.; Sideris, L.; Matsuhisa, T.; Pocard, M.; Lasser, P. Local Recurrences After Intraoperative Radiofrequency Ablation of Liver Metastases: A Comparative Study with Anatomic and Wedge Resections. Ann. Surg. Oncol. 2004, 11, 500-505. [CrossRef]

41. O'Rourke, A.P.; Haemmerich, D.; Prakash, P.; Converse, M.C.; Mahvi, D.M.; Webster, J.G. Current status of liver tumor ablation devices. Expert Rev. Med. Devices 2007, 4, 523-537. [CrossRef] [PubMed]

42. Walker, K.; Lindeque, B. The Application of Cryoprobe Therapy in Orthopedic Oncology. Orthopedics 2014, 37, 536-540. [CrossRef] [PubMed]

43. Baust, J.G.; Gage, A.A. The molecular basis of cryosurgery. BJU Int. 2005, 95, 1187-1191. [CrossRef] [PubMed]

44. Ng, K.M.; Chua, T.C.; Saxena, A.; Zhao, J.; Chu, F.; Morris, D.L. Two Decades of Experience with Hepatic Cryotherapy for Advanced Colorectal Metastases. Ann. Surg. Oncol. 2011, 19, 1276-1283. [CrossRef] [PubMed]

45. Song, P.; Sheng, L.; Sun, Y.; An, Y.; Guo, Y.; Zhang, Y. The clinical utility and outcomes of microwave ablation for colorectal cancer liver metastases. Oncotarget 2017, 8, 51792-51799. [CrossRef]

46. Gwak, J.H.; Oh, B.-Y.; Lee, R.A.; Chung, S.S.; Kim, K.H. Clinical Applications of Radio-Frequency Ablation in Liver Metastasis of Colorectal Cancer. J. Korean Soc. Coloproctology 2011, 27, 202-210. [CrossRef]

47. Cirocchi, R.; Trastulli, S.; Boselli, C.; Montedori, A.; Cavaliere, D.; Parisi, A.; Noya, G.; Abraha, I. Radiofrequency ablation in the treatment of liver metastases from colorectal cancer. Cochrane Database Syst. Rev. 2012, 13, CD006317. [CrossRef]

48. Wu, W.; Xue, Y.; Wang, D.; Xue, J.; Zhai, W.; Liang, P. A simulator for percutaneous hepatic microwave thermal ablation under ultrasound guidance. Int. J. Hyperth. 2014, 30, 429-437. [CrossRef]

49. Hinshaw, J.L.; Lubner, M.G.; Ziemlewicz, T.J.; Lee Jr, F.T.; Brace, C.L. Percutaneous Tumor Ablation Tools: Microwave, Radiofrequency, or Cryoablation-What Should You Use and Why? RadioGraphics 2014, 34, 1344-1362. [CrossRef]

50. Meijerink, M.R.; Puijk, R.S.; Van Tilborg, A.A.J.M.; Henningsen, K.H.; Fernandez, L.G.; Neyt, M.; Heymans, J.; Frankema, J.S.; De Jong, K.P.; Richel, D.J.; et al. Radiofrequency and Microwave Ablation Compared to Systemic Chemotherapy and to Partial Hepatectomy in the Treatment of Colorectal Liver Metastases: A Systematic Review and Meta-Analysis. Cardiovasc. Interv. Radiol. 2018, 41, 1189-1204. [CrossRef]

51. Lahat, E.; Eshkenazy, R.; Zendel, A.; Bar Zakai, B.; Maor, M.; Dreznik, Y.; Ariche, A. Complications after percutaneous ablation of liver tumors: A systematic review. HepatoBiliary Surg. Nutr. 2014, 3, 317-323. 
52. Puijk, R.S.; Ruarus, A.H.; Vroomen, L.G.P.H.; van Tilborg, A.A.J.M.; Scheffer, H.J.; Nielsen, K.; de Jong, M.C.; de Vries, J.J.J.; Zonderhuis, B.M.; Eker, H.H.; et al. Colorectal liver metastases: Surgery versus thermal ablation (COLLISION) - a phase III single-blind prospective randomized controlled trial. BMC Cancer 2018, 18, 821. [CrossRef]

53. Maor, E.; Ivorra, A.; Leor, J.; Rubinsky, B. The Effect of Irreversible Electroporation on Blood Vessels. Technol. Cancer Res. Treat. 2007, 6, 307-312. [CrossRef]

54. Thomson, K.R.; Cheung, W.; Ellis, S.J.; Federman, D.; Kavnoudias, H.; Loader-Oliver, D.; Roberts, S.; Evans, P.; Ball, C.M.; Haydon, A. Investigation of the Safety of Irreversible Electroporation in Humans. J. Vasc. Interv. Radiol. 2011, 22, 611-621. [CrossRef] [PubMed]

55. Lyu, T.; Wang, X.; Su, Z.; Shangguan, J.; Sun, C.; Figini, M.; Wang, J.; Yaghmai, V.; Larson, A.C.; Zhang, Z. Irreversible electroporation in primary and metastatic hepatic malignancies. Medicine 2017, 96, e6386. [CrossRef] [PubMed]

56. Jiang, C.; Davalos, R.V.; Bischof, J.C. A Review of Basic to Clinical Studies of Irreversible Electroporation Therapy. IEEE Trans. Biomed. Eng. 2015, 62, 4-20. [CrossRef] [PubMed]

57. Meijerink, M.R.; Ruarus, A.H.; Vroomen, L.G.P.H.; Puijk, R.S.; Geboers, B.; Nieuwenhuizen, S.; Bemd, B.A.T.V.D.; Nielsen, K.; de Vries, J.J.J.; van Lienden, K.P.; et al. Irreversible Electroporation to Treat Unresectable Colorectal Liver Metastases (COLDFIRE-2): A Phase II, Two-Center, Single-Arm Clinical Trial. Radiology 2021, 299, 470-480. [CrossRef]

58. van Tilborg, A.A.J.M.; Scheffer, H.J.; de Jong, M.C.; Vroomen, L.G.P.H.; Nielsen, K.; van Kuijk, C.; van den Tol, P.M.P.; Meijerink, M.R. MWA Versus RFA for Perivascular and Peribiliary CRLM: A Retrospective Patient- and Lesion-Based Analysis of Two Historical Cohorts. Cardiovasc. Intervent. Radiol. 2016, 39, 1438-1446. [CrossRef]

59. Mensel, B.; Weigel, C.; Hosten, N. Laser-Induced Thermotherapy. Advanced Structural Safety Studies 2006, 167, 69-75. [CrossRef]

60. Pacella, C.M.; Francica, G.; Di Costanzo, G.G. Laser ablation for small hepatocellular carcinoma. Radiol. Res. Pract. 2011, 595627. [CrossRef]

61. Di Costanzo, G.G.; Francica, G.; Pacella, C.M. Laser ablation for small hepatocellular carcinoma: State of the art and future per-spectives. World J. Hepatol. 2014, 6, 704-715. [CrossRef]

62. Mauri, G.; Cova, L.; Monaco, C.G.; Sconfienza, L.M.; Corbetta, S.; Benedini, S.; Ambrogi, F.; Milani, V.; Baroli, A.; Ierace, T.; et al. Benign thyroid nodules treatment using percutaneous laser ablation (PLA) and radiofrequency ablation (RFA). Int. J. Hyperth. 2016, 33, 295-299. [CrossRef]

63. Mauri, G.; Nicosia, L.; Varano, G.M.; Shyn, P.; Sartori, S.; Tombesi, P.; Di Vece, F.; Orsi, F.; Solbiati, L. Unusual tumour ablations: Report of difficult and interesting cases. ecancermedicalscience 2017, 11, 733. [CrossRef]

64. Mauri, G.; Cova, L.; Ierace, T.; Baroli, A.; Di Mauro, E.; Pacella, C.M.; Goldberg, S.N.; Solbiati, L. Treatment of Metastatic Lymph Nodes in the Neck from Papillary Thyroid Carcinoma with Percutaneous Laser Ablation. Cardiovasc. Interv. Radiol. 2016, 39, 1023-1030. [CrossRef]

65. Ion, J.C. Laser processing of engineering materials: Principles, procedure and industrial application. Boston, MA, USA, 2005.

66. Rohde, E.; Rheinbaben, I.M.-V.; Roggan, A.; Podbielska, H.; Hopf, M.; Müller, G. Interstitial Laser-Induced Thermotherapy (LITT): Comparison of In-Vitro Irradiation Effects of Nd:YAG (1064 nm) and Diode (940 nm) Laser. Med. Laser Appl. 2001, 16, 81-90. [CrossRef]

67. Pacella, C.M.; Bizzarri, G.; Magnolfi, F.; Cecconi, P.; Caspani, B.; Anelli, V.; Bianchini, A.; Valle, D.; Pacella, S.; Manenti, G.; et al. Laser Thermal Ablation in the Treatment of Small Hepatocellular Carcinoma: Results in 74 Patients. Radiology 2001, 221, 712-720. [CrossRef]

68. Di Costanzo, G.G.; D'Adamo, G.; Tortora, R. A novel needle guide system to perform percutaneous laser ablation of liver tumors using the multifiber technique. Acta. Radiol. Stockh. Swed. 1987, 54, 876-881. [CrossRef] [PubMed]

69. Tombesi, P.; Di Vece, F.; Sartori, S. Laser Ablation for Hepatic Metastases From Neuroendocrine Tumors. Am. J. Roentgenol. 2015, 204, W732. [CrossRef]

70. Sartori, S.; Di Vece, F.; Ermili, F.; Tombesi, P. Laser ablation of liver tumors: An ancillary technique, or an alternative to radiof-requency and microwave? World J. Radiol. 2017, 9, 91-96. [CrossRef] [PubMed]

71. Pacella, C.M.; Bizzarri, G.; Francica, G.; Bianchini, A.; De Nuntis, S.; Pacella, S.; Crescenzi, A.; Taccogna, S.; Forlini, G.; Rossi, Z.; et al. Percutaneous laser ablation in the treatment of hepatocellular carcinoma with small tumors: Analysis of factors af-fecting the achievement of tumor necrosis. J. Vasc. Interv. Radiol. 2005, 16, 1447-1457. [CrossRef] [PubMed]

72. Haemmerich, D.; Lee, F.T. Multiple applicator approaches for radiofrequency and microwave ablation. Int. J. Hyperth. 2005, 21, 93-106. [CrossRef] [PubMed]

73. Vogl, T.J.; Eckert, R.; Naguib, N.N.N.; Beeres, M.; Gruber-Rouh, T.; Nour-Eldin, N.-E.A. Thermal Ablation of Colorectal Lung Metastases: Retrospective Comparison Among Laser-Induced Thermotherapy, Radiofrequency Ablation, and Microwave Ablation. Am. J. Roentgenol. 2016, 207, 1340-1349. [CrossRef] [PubMed]

74. Thanos, L.; Mylona, S.; Ptohis, N.; Tsiouris, S.; Sotiropoulou, E.; Pomoni, A.; Pomoni, M. Percutaneous radiofrequency thermal ab-lation in the management of lung tumors: Presentation of clinical experience on a series of 35 patients. Diagn. Interv. Radiol. Ank. Turk. 2009, 15, 290-296.

75. Fairchild, A.H.; White, S.B. Decision Making in Interventional Oncology: Intra-arterial Therapies for Metastatic Colorectal Cancer-Y90 and Chemoembolization. Semin. Interv. Radiol. 2017, 34, 087-091. [CrossRef]

76. de Baere, T.; Tselikas, L.; Boige, V.; Ducreux, M.; Malka, D.; Goere, D.; Benahim, E.; Deschamps, F. Intra-arterial therapies for colorectal cancer liver metastases (radioembolization excluded). Bull Cancer 2017, 104, 402-406. [CrossRef] [PubMed] 
77. Gallagher, D.J.; Kemeny, N. Metastatic Colorectal Cancer: From Improved Survival to Potential Cure. Oncology 2010, 78, 237-248. [CrossRef]

78. Ammori, J.B.; Kemeny, N.E.; Fong, Y.; Cercek, A.; Dematteo, R.P.; Allen, P.J.; Kingham, T.P.; Gonen, M.; Paty, P.B.; Jarnagin, W.R.; et al. Conversion to complete resection and/or ablation using hepatic artery infusional chemotherapy in patients with unre-sectable liver metastases from colorectal cancer: A decade of experience at a single institution. Ann. Surg. Oncol. 2013, 20, 2901-2907. [CrossRef]

79. Fiorentini, G. A new tool to enhance the efficacy of chemoembolization to treat primary and metastatic hepatic tumors. Expert Opin. Drug Deliv. 2011, 8, 409-413. [CrossRef]

80. Kemeny, N.E.; Melendez, F.D.H.; Capanu, M.; Paty, P.B.; Fong, Y.; Schwartz, L.H.; Jarnagin, W.R.; Patel, D.; D’Angelica, M. Conversion to Resectability Using Hepatic Artery Infusion Plus Systemic Chemotherapy for the Treatment of Unresectable Liver Metastases From Colorectal Carcinoma. J. Clin. Oncol. 2009, 27, 3465-3471. [CrossRef]

81. Luo, J.; Guo, R.-P.; Lai, E.C.H.; Zhang, Y.-J.; Lau, W.Y.; Chen, M.-S.; Shi, M. Transarterial chemoembolization for unresectable hepato-cellular carcinoma with portal vein tumor thrombosis: A prospective comparative study. Ann. Surg. Oncol. 2011, 18, 413-420. [CrossRef] [PubMed]

82. Martin, R.C.G.; Scoggins, C.R.; Schreeder, M.T.; Rilling, W.S.; Laing, C.J.; Tatum, C.M.; Kelly, L.R.; Garcia-Monaco, R.D.; Sharma, V.R.; Crocenzi, T.S.; et al. Randomized controlled trial of irinotecan drug-eluting beads with simultaneous FOLFOX and bevacizumab for patients with unresectable colorectal liver-limited metastasis. Cancer 2015, 121, 3649-3658. [CrossRef]

83. Mauri, G.; Varano, G.M.; Della Vigna, P.; Bonomo, G.; Monfardini, L.; Zampino, M.G.; Ravenda, P.S.; Orsi, F. Transarterial Embolization with Small-Size Particles Loaded with Irinotecan for the Treatment of Colorectal Liver Metastases: Results of the MIRACLE III Study. Cardiovasc. Interv. Radiol. 2018, 41, 1708-1715. [CrossRef]

84. Mauri, G.; Varano, G.M.; Orsi, F. TAE for HCC: When the Old Way is Better than the New Ones!!! Cardiovasc. Interv. Radiol. 2016, 39, 799-800. [CrossRef]

85. Brown, D.B.; Gould, J.E.; Gervais, D.A.; Goldberg, S.N.; Murthy, R.; Millward, S.F.; Rilling, W.S.; Geschwind, J.-F.S.; Salem, R.; Vedantham, S.; et al. Transcatheter Therapy for Hepatic Malignancy: Standardization of Terminology and Reporting Criteria. J. Vasc. Interv. Radiol. 2007, 18, 1469-1478. [CrossRef]

86. Marelli, L.; Stigliano, R.; Triantos, C.; Senzolo, M.; Cholongitas, E.; Davies, N.; Tibballs, J.; Meyer, T.; Patch, D.W.; Burroughs, A.K. Transarterial Therapy for Hepatocellular Carcinoma: Which Technique Is More Effective? A Systematic Review of Cohort and Randomized Studies. Cardiovasc. Interv. Radiol. 2007, 30, 6-25. [CrossRef] [PubMed]

87. Ridge, J.A.; Bading, J.R.; Gelbard, A.S. Perfusion of colorectal hepatic metastases. Relative distribution of flow from the hepatic artery and portal vein. Cancer 1987, 59, 1547-1553. [CrossRef]

88. Arai, Y.; Ohtsu, A.; Sato, Y.; Aramaki, T.; Kato, K.; Hamada, M.; Muro, K.; Yamada, Y.; Inaba, Y.; Shimada, Y.; et al. Phase I/II Study of Radiologic Hepatic Arterial Infusion of Fluorouracil Plus Systemic Irinotecan for Unresectable Hepatic Metastases from Colorectal Cancer: Japan Clinical Oncology Group Trial 0208-DI. J. Vasc. Interv. Radiol. 2012, 23, 1261-1267. [CrossRef] [PubMed]

89. Hildebrandt, B.; Pech, M.; Nicolaou, A.; Langrehr, J.M.; Kurcz, J.; Bartels, B.; Miersch, A.; Felix, R.; Neuhaus, P.; Riess, H.; et al. Interventionally implanted port catheter systems for hepatic arterial infusion of chemotherapy in patients with colorectal liver metastases: A phase II-study and historical comparison with the surgical approach. BMC Cancer 2007, 7, 69. [CrossRef] [PubMed]

90. Oberfield, R.A.; Sampson, E.; Heatley, G.J. Hepatic artery infusion chemotherapy for metastatic colorectal cancer to the liver at the lahey clinic: Comparison between two methods of treatment, surgical versus percutaneous catheter placement. Am J Clin Oncol 2004, 27, 376-383. [CrossRef] [PubMed]

91. Barnett, K.T.; Malafa, M.P. Complications of Hepatic Artery Infusion: A Review of 4580 Reported Cases. Int. J. Pancreatol. 2001, 30, 147-160. [CrossRef]

92. Dzodic, R.; Gomez-Abuin, G.; Rougier, P.; Bonnay, M.; Ardouin, P.; Gouyette, A.; Rixe, O.; Ducreux, M.; Munck, J.-N. Pharmacokinetic advantage of intra-arterial hepatic oxaliplatin administration: Comparative results with cisplatin using a rabbit VX2 tumor model. Anti-Cancer Drugs 2004, 15, 647-650. [CrossRef]

93. Munck, J.N.; Riggi, M.; Rougier, P.; Chabot, G.G.; Ramirez, L.H.; Zhao, Z.; Bognel, C.; Ardouin, P.; Herait, P.; Gouyette, A. Pharmacokinetic and pharmacodynamic advantages of pirarubicin over adriamycin after intraarterial hepatic administration in the rabbit VX2 tumor model. Cancer Res. 1993, 53, 1550-1554.

94. Baggiani, A.; Ierardi, A.M.; Caspani, B.; Motta, F.; Toniolo, D.; Belloni, P.; Setola, E.; Campagnoli, E.; Tempini, S.; Crocchiolo, R.; et al. Hypoxic liver perfusion with mitomycin-C for treating multifocal metastases and unresectable primary tumours: A single-centre series of 42 patients. La. Radiol. Medica 2011, 116, 1239-1249. [CrossRef]

95. Aldrighetti, L.; Arru, M.; Ronzoni, M.; Salvioni, M.; Villa, E.; Ferla, G. Extrahepatic biliary stenoses after hepatic arterial infusion (HAI) of floxuridine (FUdR) for liver metastases from colorectal cancer. Hepatogastroenterology 2001, 48, 1302-1307. [PubMed]

96. Ducreux, M.; Ychou, M.; Laplanche, A.; Gamelin, E.; Lasser, P.; Husseini, F.; Quenet, F.; Viret, F.; Jacob, J.-H.; Boige, V.; et al. Hepatic Arterial Oxaliplatin Infusion Plus Intravenous Chemotherapy in Colorectal Cancer With Inoperable Hepatic Metastases: A Trial of the Gastrointestinal Group of the Fédération Nationale des Centres de Lutte Contre le Cancer. J. Clin. Oncol. 2005, 23, 4881-4887. [CrossRef] [PubMed]

97. Kemeny, N.; Jarnagin, W.; Paty, P.; Gonen, M.; Schwartz, L.; Morse, M.; Leonard, G.; D’Angelica, M.; DeMatteo, R.; Blumgart, L.; et al. Phase I Trial of Systemic Oxaliplatin Combination Chemotherapy With Hepatic Arterial Infusion in Patients With Unresectable Liver Metastases From Colorectal Cancer. J. Clin. Oncol. 2005, 23, 4888-4896. [CrossRef] 
98. Kemeny, N.; Huang, Y.; Cohen, A.M.; Shi, W.; Conti, J.A.; Brennan, M.F.; Bertino, J.R.; Turnbull, A.D.; Sullivan, D.; Stockman, J.; et al. Hepatic arterial infusion of chemotherapy after resection of hepatic metastases from colorectal cancer. N. Engl. J. Med. 1999, 341, 2039-2048. [CrossRef] [PubMed]

99. Mitry, E.; Fields, A.L.; Bleiberg, H.; Labianca, R.; Portier, G.; Tu, D.; Nitti, D.; Torri, V.; Elias, D.; O'Callaghan, C.; et al. Adjuvant Chemotherapy After Potentially Curative Resection of Metastases From Colorectal Cancer: A Pooled Analysis of Two Randomized Trials. J. Clin. Oncol. 2008, 26, 4906-4911. [CrossRef]

100. Goere, D.; Benhaim, L.; Bonnet, S.; Malka, D.; Faron, M.; Elias, D.; Lefevre, J.H.; Deschamps, F.; Dromain, C.; Boige, V.; et al. Adjuvant chemotherapy after resection of colorectal liver metastases in patients at high risk of hepatic recur-rence: A comparative study between hepatic arterial infusion of oxaliplatin and modern systemic chemotherapy. Ann. Surg. 2013, 257, 114-120. [CrossRef]

101. Goéré, D.; Deshaies, I.; de Baere, T.; Boige, V.; Malka, D.; Dumont, F.; Dromain, C.; Ducreux, M.; Elias, D. Prolonged Survival of Initially Unresectable Hepatic Colorectal Cancer Patients Treated With Hepatic Arterial Infusion of Oxaliplatin Followed by Radical Surgery of Metastases. Ann. Surg. 2010, 251, 686-691. [CrossRef]

102. Willowson, K.P.; Hayes, A.R.; Chan, D.L.H.; Tapner, M.; Bernard, E.J.; Maher, R.; Pavlakis, N.; Clarke, S.J.; Bailey, D.L. Clinical and imag-ing-based prognostic factors in radioembolisation of liver metastases from colorectal cancer: A retrospective exploratory analysis. EJNMMI Res. 2017, 7, 46. [CrossRef]

103. Kennedy, A.; Cohn, M.; Coldwell, D.M.; Drooz, A.; Ehrenwald, E.; Kaiser, A.; Nutting, C.W.; Rose, S.C.; Wang, E.A.; Savin, M.A. Updated survival outcomes and analysis of long-term survivors from the MORE study on safety and efficacy of radioembolization in patients with unresectable colorectal cancer liver metastases. J. Gastrointest. Oncol. 2017, 8, 614-624. [CrossRef]

104. Kennedy, A.S.; Nutting, C.; Coldwell, D.; Gaiser, J.; Drachenberg, C. Pathologic response and microdosimetry of $90 \mathrm{Y}$ microspheres in man: Review of four explanted whole livers. Int. J. Radiat. Oncol. 2004, 60, 1552-1563. [CrossRef] [PubMed]

105. Campbell, A.M.; Bailey, I.H.; A Burton, M. Tumour dosimetry in human liver following hepatic yttrium-90 microsphere therapy. Phys. Med. Biol. 2001, 46, 487-498. [CrossRef] [PubMed]

106. Dawson, L.A.; McGinn, C.J.; Normolle, D.; Haken, R.K.T.; Walker, S.; Ensminger, W.; Lawrence, T.S. Escalated Focal Liver Radiation and Concurrent Hepatic Artery Fluorodeoxyuridine for Unresectable Intrahepatic Malignancies. J. Clin. Oncol. 2000, 18, 2210-2218. [CrossRef]

107. Reinders, M.T.M.; Mees, E.; Powerski, M.J.; Bruijnen, R.C.G.; Bosch, M.A.A.J.V.D.; Lam, M.G.E.H.; Smits, M.L.J. Radioembolisation in Europe: A Survey Amongst CIRSE Members. Cardiovasc. Interv. Radiol. 2018, 41, 1579-1589. [CrossRef]

108. Nicolay, N.H.; Berry, D.P.; Sharma, R.A. Liver metastases from colorectal cancer: Radioembolization with systemic therapy. Nat. Rev. Clin. Oncol. 2009, 6, 687-697. [CrossRef] [PubMed]

109. Van Hazel, G.; Blackwell, A.; Anderson, J.; Price, D.; Moroz, P.; Bower, G.; Cardaci, G.; Gray, B. Randomised phase 2 trial of SIR-spheres plus fluorouracil/leucovorin chemotherapy versus fluorouracil/leucovorin chemotherapy alone in advanced colorectal cancer. J. Surg. Oncol. 2004, 88, 78-85. [CrossRef] [PubMed]

110. Sharma, R.A.; Van Hazel, G.A.; Morgan, B. Radioembolization of liver metastases from colorectal cancer using Yttrium-90 mi-crospheres with concomitant systemic oxaliplatin, fluorouracil, and leucovorin chemotherapy. J. Clin. Oncol. 2007, 25, 1099-1106. [CrossRef]

111. Van Hazel, G.A.; Heinemann, V.; Sharma, N.K. SIRFLOX: Randomized phase III trial comparing first-line mFOLFOX6 (Plus or Minus Bevacizumab) versus mFOLFOX6 (Plus or Minus Bevacizumab) plus selective internal radiation therapy in patients with metastatic colorectal cancer. J. Clin. Oncol. 2016, 34, 1723-1731. [CrossRef]

112. Garin, E.; Tselikas, L.; Guiu, B.; Chalaye, J.; Edeline, J.; de Baere, T.; Assenat, E.; Tacher, V.; Robert, C.; Terroir-Cassou-Mounat, M.; et al. Personalised versus standard dosimetry approach of selective internal radiation therapy in patients with locally advanced hepatocellular carcinoma (DOSISPHERE-01): A randomised, multicentre, open-label phase 2 trial. Lancet Gastroenterol. Hepatol. 2021, 6, 17-29. [CrossRef]

113. Wasan, H.S.; Gibbs, P.; Sharma, N.K.; Taieb, J.; Heinemann, V.; Ricke, J.; Peeters, M.; Findlay, M.; Weaver, A.; Mills, J.; et al. First-line se-lective internal radiotherapy plus chemotherapy versus chemotherapy alone in patients with liver metastases from colorectal cancer (FOXFIRE, SIRFLOX, and FOXFIRE-Global): A combined analysis of three multicentre, randomised, phase 3 trials. Lancet Oncol. 2017, 18, 1159-1171. [CrossRef]

114. Robb, M.A.; McInnes, P.M.; Califf, R.M. Biomarkers and surrogate endpoints: Developing common terminology and definitions. JAMA 2016, 315, 1107-1108. [CrossRef]

115. Califf, R.M. Biomarker definitions and their applications. Exp. Biol. Med. 2018, 243, 213-221. [CrossRef]

116. FDA-NIH Biomarker Working Group. BEST (Biomarkers, EndpointS, and other Tools) Resource; Food and Drug Administration: Silver Spring, MD, USA; National Institutes of Health: Bethesda, MD, USA, 2016.

117. Siena, S.; Sartore-Bianchi, A.; Di Nicolantonio, F.; Balfour, J.; Bardelli, A. Biomarkers Predicting Clinical Outcome of Epidermal Growth Factor Receptor-Targeted Therapy in Metastatic Colorectal Cancer. J. Natl. Cancer Inst. 2009, 101, 1308-1324. [CrossRef]

118. Knijn, N.; Mekenkamp, L.J.M.; Klomp, M.; Vink-Börger, M.E.; Van Tol, J.; Teerenstra, S.; Meijer, J.W.R.; Tebar, M.; A Riemersma, S.; Van Krieken, J.H.J.M.; et al. KRAS mutation analysis: A comparison between primary tumours and matched liver metastases in 305 colorectal cancer patients. Br. J. Cancer 2011, 104, 1020-1026. [CrossRef]

119. Brudvik, K.W.; Kopetz, S.E.; Li, L.; Conrad, C.; Aloia, T.A.; Vauthey, J. Meta-analysis of KRAS mutations and survival after resection of colorectal liver metastases. Br. J. Surg. 2015, 102, 1175-1183. [CrossRef] 
120. Brudvik, K.W.; Mise, Y.; Chung, M.H.; Chun, Y.S.; Kopetz, S.E.; Passot, G.; Conrad, C.; Maru, D.M.; Aloia, T.A.; Vauthey, J.-N.; et al. RAS Mutation Predicts Positive Resection Margins and Narrower Resection Margins in Patients Undergoing Resection of Colorectal Liver Metastases. Ann. Surg. Oncol. 2016, 23, 2635-2643. [CrossRef] [PubMed]

121. Vauthey, J.-N.; Zimmitti, G.; Kopetz, S.E.; Shindoh, J.; Chen, S.S.; Andreou, A.; Curley, S.A.; Aloia, T.A.; Maru, D.M. RAS Mutation Status Predicts Survival and Patterns of Recurrence in Patients Undergoing Hepatectomy for Colorectal Liver Metastases. Ann. Surg. 2013, 258, 619-627. [CrossRef] [PubMed]

122. Okuno, M.; Goumard, C.; Kopetz, S.; Vega, E.A.; Joechle, K.; Mizuno, T.; Omichi, K.; Tzeng, C.-W.D.; Chun, Y.S.; Vauthey, J.-N.; et al. RAS Mutation is Associated with Unsalvageable Recurrence Following Hepatectomy for Colorectal Cancer Liver Metastases. Ann. Surg. Oncol. 2018, 25, 2457-2466. [CrossRef] [PubMed]

123. Odisio, B.C.; Yamashita, S.; Huang, S.Y. Local tumour progression after percutaneous ablation of colorectal liver metastases ac-cording to RAS mutation status. Br. J. Surg. 2017, 104, 760-768. [CrossRef]

124. Calandri, M.; Yamashita, S.; Gazzera, C.; Fonio, P.; Veltri, A.; Bustreo, S.; Sheth, R.A.; Yevich, S.M.; Vauthey, J.N.; Odisio, B.C. Ablation of colorectal liver metastasis: Interaction of ablation margins and RAS mutation profiling on local tumor progression-free survival. Eur. Radiol. 2018, 28, 2727-2734. [CrossRef]

125. Calandri, M.; Odisio, B.C. Tailoring ablation strategies for colorectal liver metastases based upon rat sarcoma viral oncogene mutation status. Chin. Clin. Oncol. 2019, 8, 51. [CrossRef] [PubMed]

126. Yamashita, S.; Chun, Y.S.; Kopetz, S.E.; Vauthey, J. Biomarkers in colorectal liver metastases. Br. J. Surg. 2018, 105, 618-627. [CrossRef] [PubMed]

127. Kopetz, S.; Desai, J.; Chan, E.; Hecht, J.R.; O’Dwyer, P.J.; Maru, D.M.; Morris, V.; Janku, F.; Dasari, A.; Chung, W.; et al. Phase II Pilot Study of Vemurafenib in Patients With Metastatic BRAF-Mutated Colorectal Cancer. J. Clin. Oncol. 2015, 33, 4032-4038. [CrossRef] [PubMed]

128. Yaeger, R.; Cercek, A.; Chou, J.F.; Sylvester, B.E.; Kemeny, N.E.; Hechtman, J.F.; Ladanyi, M.; Rosen, N.; Weiser, M.R.; Capanu, M.; et al. BRAF mutation predicts for poor outcomes after metastasectomy in patients with metastatic colorectal cancer. Cancer 2014, 120, 2316-2324. [CrossRef] [PubMed]

129. Passiglia, F.; Bronte, G.; Bazan, V.; Galvano, A.; Vincenzi, B.; Russo, A. Can KRAS and BRAF mutations limit the benefit of liver resection in metastatic colorectal cancer patients? A systematic review and meta-analysis. Crit. Rev. Oncol. 2016, 99, 150-157. [CrossRef]

130. Jones, J.C.; Renfro, L.A.; Al-Shamsi, H.O.; Schrock, A.B.; Rankin, A.; Zhang, B.Y.; Kasi, P.M.; Voss, J.S.; Leal, A.; Sun, J.; et al. Non-V600BRAF Mutations Define a Clinically Distinct Molecular Subtype of Metastatic Colorectal Cancer. J. Clin. Oncol. 2017, 35, 2624-2630. [CrossRef]

131. Weisenberger, D.J.; Siegmund, K.D.; Campan, M.; Young, J.; Long, T.I.; Faasse, M.A.; Kang, G.H.; Widschwendter, M.; Weener, D.; Buchanan, D.; et al. CpG island methylator phenotype underlies sporadic microsatellite instability and is tightly associated with BRAF mutation in colorectal cancer. Nat. Genet. 2006, 38, 787-793. [CrossRef]

132. Venderbosch, S.; Nagtegaal, I.; Maughan, T.S.; Smith, C.G.; Cheadle, J.P.; Fisher, D.; Kaplan, R.; Quirke, P.; Seymour, M.T.; Richman, S.D.; et al. Mismatch Repair Status and BRAF Mutation Status in Metastatic Colorectal Cancer Patients: A Pooled Analysis of the CAIRO, CAIRO2, COIN, and FOCUS Studies. Clin. Cancer Res. 2014, 20, 5322-5330. [CrossRef]

133. Vogelstein, B.; Lane, D.; Levine, A.J. Surfing the p53 network. Nat. Cell Biol. 2000, 408, 307-310. [CrossRef]

134. Leslie, A.; Carey, F.A.; Pratt, N.R.; Steele, R.J. The colorectal adenoma-carcinoma sequence. Br. J. Surg. 2002, 89, 845-860. [CrossRef]

135. Garcia-Aguilar, J.; Chen, Z.; Smith, D.D.; Li, W.; Madoff, R.D.; Cataldo, P. Identification of a biomarker profile associated with re-sistance to neoadjuvant chemoradiation therapy in rectal cancer. Ann. Surg. 2011, 254, 486-492. [CrossRef]

136. Chun, Y.S.; Passot, G.; Yamashita, S.; Nusrat, M.; Katsonis, P.; Loree, J.; Conrad, C.; Tzeng, C.-W.D.; Xiao, L.; Aloia, T.A.; et al. Deleterious Effect of RAS and Evolutionary High-risk TP53 Double Mutation in Colorectal Liver Metastases. Ann. Surg. 2019, 269, 917-923. [CrossRef] [PubMed]

137. Yamashita, S.; Chun, Y.-S.; Kopetz, S.E.; Maru, D.; Conrad, C.; Aloia, T.A.; Vauthey, J.-N. APC and PIK3CA Mutational Cooperativity Predicts Pathologic Response and Survival in Patients Undergoing Resection for Colorectal Liver Metastases. Ann. Surg. 2020, 272, 1080-1085. [CrossRef] [PubMed]

138. Ziv, E.; Bergen, M.; Yarmohammadi, M.; Edward Boas, F.; Petre, N.; Sofocleous, C.T.; Yaeger, R.; Solit, D.B.; Solomon, S.B.; Erinjeri, J.P. PI3K pathway mutations are associated with longer time to local progression after radioembolization of colorectal liver metastases. Oncotarget 2017, 8, 23529-23538. [CrossRef] [PubMed]

139. Zarour, L.R.; Anand, S.; Billingsley, K.G.; Bisson, W.H.; Cercek, A.; Clarke, M.F.; Coussens, L.M.; Gast, C.E.; Geltzeiler, C.B.; Hansen, L.; et al. Colorectal Cancer Liver Metastasis: Evolving Paradigms and Future Directions. Cell. Mol. Gastroenterol. Hepatol. 2017, 3, 163-173. [CrossRef]

140. Calandri, M.; Siravegna, G.; Yevich, S.M.; Stranieri, G.; Gazzera, C.; Kopetz, S.; Fonio, P.; Gupta, S.; Bardelli, A.; Veltri, A.; et al. Liquid biopsy, a paradigm shift in oncology: What interventional radiologists should know. Eur. Radiol. 2020, 30, $4496-4503$. [CrossRef]

141. Cohen, S.J.; Punt, C.J.A.; Iannotti, N.; Saidman, B.H.; Sabbath, K.D.; Gabrail, N.Y.; Picus, J.; Morse, M.; Mitchell, E.; Miller, M.C.; et al. Relationship of Circulating Tumor Cells to Tumor Response, Progression-Free Survival, and Overall Survival in Patients With Metastatic Colorectal Cancer. J. Clin. Oncol. 2008, 26, 3213-3221. [CrossRef] 
142. Diaz, L.A.; Bardelli, A. Liquid Biopsies: Genotyping Circulating Tumor DNA. J. Clin. Oncol. 2014, 32, 579-586. [CrossRef]

143. Siravegna, G.; Bardelli, A. Genotyping cell-free tumor DNA in the blood to detect residual disease and drug resistance. Genome Biol. 2014, 15, 449. [CrossRef]

144. Parikh, A.R.; Leschhiner, I. Liquid versus tissue biopsy for detecting acquired resistance and tumor heterogeneity in gastrointestinal cancers. Nat. Med. 2019, 25, 1415-1421. [CrossRef]

145. d'Othee, J.B.; Sofocleous, C.T.; Hanna, N.; Lewandowski, R.J.; Soulen, M.C.; Vauthey, J.N.; Cohen, S.J.; Venook, A.L.; Johnson, M.S.; Kennedy, A.S.; et al. Development of a research agenda for the management of metastatic colorectal cancer: Proceedings from a multidisciplinary research consensus panel. J. Vasc. Interv. Radiol. 2012, 23, 153-163.

146. Shady, W.; Petre, E.N.; Gonen, M.; Erinjeri, J.P.; Brown, K.T.; Covey, A.M.; Alago, W.; Durack, J.C.; Maybody, M.; Brody, L.A.; et al. Percutaneous radiofrequency ablation of colorectal cancer liver metastases: Factors affecting outcomes - a 10-year experience at a singe center. Radiology 2016, 278, 601-611. [CrossRef] [PubMed]

147. Snoeren, N.; Huiskens, J.; Rijken, A.M.; Van Hillegersberg, R.; Van Erkel, A.R.; Slooter, G.D.; Klaase, J.M.; Tol, P.M.V.D.; Kate, F.J.W.T.; Jansen, M.C.; et al. Viable Tumor Tissue Adherent to Needle Applicators after Local Ablation: A Risk Factor for Local Tumor Progression. Ann. Surg. Oncol. 2011, 18, 3702-3710. [CrossRef]

148. Sotirchos, V.S.; Fujisawa, S.; Vakiani, E.; Solomon, S.B.; Manova-Todorova, K.O.; Sofocleous, C.T. Fluorescent Tissue Assessment of Colorectal Cancer Liver Metastases Ablation Zone: A Potential Real-Time Biomarker of Complete Tumor Ablation. Ann. Surg. Oncol. 2019, 26, 1833-1840. [CrossRef] [PubMed]

149. Cornelis, F.H.; Petre, E.N.; Vakiani, E. Immediate postablation 18F-FDG injection and corresponding SUV are surrogate biomarkers of local tumor progression after thermal ablation of colorectal carcinoma liver metastases. J. Nucl. Med. 2018, 59, 1360-1365. [CrossRef]

150. Shady, W.; Sotirchos, V.S. Surrogate imaging biomarkers of response of colorectal liver metastases after salvage radioembo-lization using 90Y-loaded resin microspheres. Am. J. Roentgenol. 2016, 207, 661-670. [CrossRef] [PubMed]

151. Barabasch, A.; Heinzel, A.; Bruners, P.; Kraemer, N.A.; Kuhl, C.K. Diffusion-weighted MRI Is Superior to PET/CT in Predicting Survival of Patients Undergoing 90Y Radioembolization of Hepatic Metastases. Radiology 2018, 288, 764-773. [CrossRef] [PubMed]

152. Shady, W.; Kishore, S.; Gavane, S.; Do, R.K.; Osborne, J.R.; Ulaner, G.; Gonen, M.; Ziv, E.; Boas, F.E.; Sofocleous, C.T. Metabolic tumor volume and total lesion glycolysis on FDG-PET/CT can predict overall survival after 90Y radioembolization of colorectal liver metastases: A comparison with SUVmax, SUVpeak, and RECIST 1.0. Eur. J. Radiol. 2016, 85, 1224-1231. [CrossRef]

153. Lahrsow, M.; Albrecht, M.H.; Bickford, M.W.; Vogl, T.J. Predicting Treatment Response of Colorectal Cancer Liver Metastases to Conventional Lipiodol-Based Transarterial Chemoembolization Using Diffusion-Weighted MR Imaging: Value of Pre-treatment Apparent Diffusion Coefficients (ADC) and ADC Changes Under Therapy. Cardiovasc. Intervent. Radiol. 2017, 40, 852-859. [PubMed] 